\title{
Measuring the Impact of Knowledge Management on the Effectiveness in the Classroom Delivery using Multiple Regression
}

\author{
Sivagami R, Umamaheswari D
}

\begin{abstract}
Knowledge management is considered as the integrated approach which involves in identifying, managing and sharing the critical know-how, enable in enhancing the experiences of the individual and increasing the intellectual capital of the human resources in the education sector. Knowledge management is considered as the critical fields which enable in guiding the educational institutions and the students in generating new knowledge, storing them and apply when required. Hence, to apprehend the effect of knowledge management, a clear picture of the approach and framework needs to be determined. Knowledge management possess greater impact on the effectiveness in the classroom delivery, the knowledge generation is considered as the critical factor in the KM model which was stated earlier. Hence, educational institutions tend to focus on the three specified critical areas: Knowledge generation; Knowledge storage and Knowledge application. These aspects will enable the trainers to enhance the effectiveness of classroom delivery in educational institutions.
\end{abstract}

Index Terms: Knowledge management, Knowledge generation, Multiple regression.

\section{INTRODUCTION}

Knowledge management is considered as the integrated approach which involves in identifying, managing and sharing the critical know-how, enable in enhancing the experiences of the individual and increasing the intellectual capital of the human resources in the education sector. Through the assistance of managing the knowledge, the tutors enable in improving the efficiency of the students in the classroom, allow them to learn and understand more effectively and efficiently which enable in providing a clear and better foundation for their future. (Friesl, 2011). The knowledge management systems tend is mainly designed with a purview in managing the knowledge of the individuals, the educational institutions which effectively manager and leverage the overall knowledge of the individuals tend to create more value to the individuals and achieve superior competitive advantage for the future. Human resource training is considered as the primary approach which enable in eliciting and reinforcing the knowledge of the individuals and expertise which the student's requires. Also it can be

Revised Version Manuscript Received on 16 September, 2019.

Sivagami R, Department of Management Studies, Periyar Maniammai Institute of Science \& Technology, Thanjavur, India

Umamaheswari D, Department of Commerce, Periyar Maniammai Institute of Science \& Technology, Thanjavur, India noted that the KMS tend to support the overall management of knowledge through the creation of network inside the educational institutions among the students and teachers. There are two main approaches which is involved in creating and implementing the knowledge management system, the process approach and the other is the generic approach. (Bhatt,2000). The process approach focuses applies the knowledge by the participants in the process, task or project so as to enhance the effectiveness of learning in the class room. This approach focuses in enhancing the information and knowledge of the process which are mainly located and is being provided who needs them. Furthermore, this approach requires the KMS to capture the minimal context because the users are mainly assumed to understand the knowledge which is being provided by the teachers.

\section{REVIEW OF LITERATURE}

Every healthy educational institution creates knowledge. In collaboration with other environments and educational institutions, they absorb information gathering their experiences, values and internal rules, converted into knowledge and acting accordingly. KG contains all activities that create new knowledge for the individual, team or world. Knowledge coding and registers are knowledge that can be reused by a person or educational institution. (Tan, 2011) KG's activities within a university department are scientific research, creativity and innovation. The process of knowledge creation requires no generation of new knowledge. In many cases, educational institutions may prefer to acquire knowledge from other sources and apply it on their own use. Educational institutions acquire knowledge in many ways. Counterfeiting, benchmarking, reproduction, replacement purchases, outsourcing and discoveries are ways to acquire knowledge. (Dessler, 2010)

KS procedures include keeping knowledge and maintaining, maintaining, organizing and facilitating access and recovery. This process represents the organizational memory of educational institutions. Knowledge must be available in a timely and appropriate manner, in a language that is understandable to employees in order to reduce value and research efforts. Organizational knowledge can be stored in three basic ways: First, you choose valuable maintenance skills. Second, preserve, document and archive the knowledge. Third, load this memory from time to time. (Davis, 2009). Knowledge storage and codification is important not only for the effective use of knowledge, but also for the recovery of this knowledge to educational institutions and not for those who use it. They know. This is 
the final process in knowledge management processes and the most important. Without the application, KA is useless. The value of shared knowledge has increased. KA refers to the actual use of the collected or generated knowledge. Sufficient attention should be paid to the effective use of the knowledge available to those who need it. In addition, the translation of knowledge should strive to achieve the goals of educational institutions that develop and adapt. (Seleim, 2007)

\section{RESEARCH METHODOLOGY}

The researcher intends to apply descriptive research methodology for performing the research, the method will enable the researcher to observe and describe the overall behaviour of the subject without influencing them in any manner. The researcher uses survey method for performing the research activity, the researcher intends to collect the data using the convenience sampling method. Due to the time constraint, the sample population is considered as 115 .

\section{A. Review Objective}

The main purpose of the research is to analyse the impact of knowledge management on the effectiveness in classroom delivery. The research objectives can be stated as

- To understand the impact of knowledge management process in supporting the effectiveness in classroom delivery

- To apprehend the key factor of knowledge management process in contributing the effectiveness.

\section{B. Research Scope}

Knowledge management is considered as the critical field which enables in guiding the educational institutions and the students in generating new knowledge, storing them and applies when required. Hence, to apprehend the effect of knowledge management, a clear picture of the approach and framework needs to be determined. This research is focused in analysing the impact of knowledge management towards the effectiveness of classroom delivery in educational institution. The KM model tends to provide the overall framework so as to identify the different types of knowledge which is available in the educational institutions. (Neumann, 2011)

\section{Conceptual Framework}

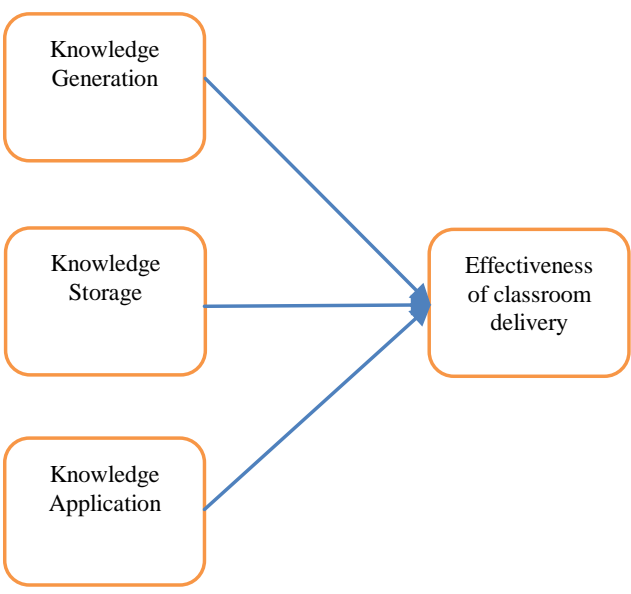

\section{DATA ANALYSIS}

The following is the detailed descriptive analysis of the data

\begin{tabular}{|c|c|c|}
\hline Gender & Frequency & Percent \\
\hline Male & 99 & 86.1 \\
\hline Female & 16 & 13.9 \\
\hline Total & 115 & 100.0 \\
\hline Age & Frequency & Percent \\
\hline Less than 30 years & 37 & 32.2 \\
\hline $31-40$ years & 32 & 27.8 \\
\hline 41 - 50 years & 15 & 13.0 \\
\hline Above 50 years & 31 & 27.0 \\
\hline Total & 115 & 100.0 \\
\hline Marital status & Frequency & Percent \\
\hline Married & 73 & 63.5 \\
\hline Unmarried & 42 & 36.5 \\
\hline Total & 115 & 100.0 \\
\hline Type of family & Frequency & Percent \\
\hline Nuclear Family & 73 & 63.5 \\
\hline Joint Family & 42 & 36.5 \\
\hline Total & 115 & 100.0 \\
\hline Annual income & Frequency & Percent \\
\hline Less than 4 Lakhs & 85 & 73.9 \\
\hline 4 - 8 Lakhs & 29 & 25.2 \\
\hline Above 12 Lakhs & 1 & .9 \\
\hline Total & 115 & 100.0 \\
\hline Years of experience & Frequency & Percent \\
\hline $\begin{array}{l}\text { Less than } 3 \text { years of } \\
\text { experience }\end{array}$ & 35 & 30.4 \\
\hline $3-5$ years & 25 & 21.7 \\
\hline $5-7$ years & 14 & 12.2 \\
\hline 7 - 10 years & 9 & 7.8 \\
\hline Above 10 years & 32 & 27.8 \\
\hline Total & 115 & 100.0 \\
\hline
\end{tabular}

From the analysis it is noted that the $86.1 \%$ of the respondents are male, $32.2 \%$ of the respondents were in the age group of less than 30 years, $63.5 \%$ of the respondents were married and are living in a nuclear family, $73.9 \%$ of the respondents were earning less than 4 lakhs and $30.4 \%$ of the respondents were possessing an experience of less than 3 years of age. 
Correlation analysis

\begin{tabular}{|l|l|c|c|c|}
\hline \multicolumn{5}{|c|}{ Correlations } \\
\hline \multirow{2}{|c|}{} & $\begin{array}{c}\text { Knowl } \\
\text { edge } \\
\text { generat } \\
\text { ion }\end{array}$ & $\begin{array}{c}\text { Knowl } \\
\text { edge } \\
\text { storage }\end{array}$ & $\begin{array}{c}\text { Knowled } \\
\text { ge } \\
\text { applicati } \\
\text { on }\end{array}$ \\
\hline $\begin{array}{l}\text { Knowledge } \\
\text { generation }\end{array}$ & $\begin{array}{l}\text { Pearson } \\
\text { Correlation }\end{array}$ & 1 & $.543^{* *}$ & $.334^{* *}$ \\
\cline { 2 - 5 } & $\begin{array}{l}\text { Sig. } \\
\text { (2-tailed) }\end{array}$ & & .000 & .000 \\
\cline { 2 - 5 } & $\mathrm{N}$ & 115 & 115 & 115 \\
\hline \multirow{3}{*}{$\begin{array}{l}\text { Knowledge } \\
\text { storage }\end{array}$} & $\begin{array}{l}\text { Pearson } \\
\text { Correlation }\end{array}$ & $.543^{* *}$ & 1 & $.501^{* *}$ \\
\cline { 2 - 5 } & $\begin{array}{l}\text { Sig. } \\
\text { (2-tailed) }\end{array}$ & .000 & & .000 \\
\cline { 2 - 5 } & $\mathrm{N}$ & 115 & 115 & 115 \\
\hline \multirow{2}{*}{$\begin{array}{l}\text { Knowledge } \\
\text { application }\end{array}$} & $\begin{array}{l}\text { Pearson } \\
\text { Correlation }\end{array}$ & $.334^{* *}$ & $.501^{* *}$ & 1 \\
\cline { 2 - 5 } & $\begin{array}{l}\text { Sig. } \\
\text { (2-tailed) }\end{array}$ & .000 & .000 & \\
\cline { 2 - 5 } & $\mathrm{N}$ & 115 & 115 & 115 \\
\hline \multirow{2}{*}{$* *$ Correlation is significant at the 0.01 level (2-tailed). } \\
\hline
\end{tabular}

From the above analysis it can be stated that the correlation between the knowledge generation and knowledge storage is at 0.543 showing they are moderately positive correlated, similarly the correlation between the knowledge generation and knowledge application is at 0.334 showing they are less positive correlated. Also, it is identified that correlation between the knowledge storage and knowledge application is at 0.501 showing they are moderately positive correlated

\section{Multiple regression analysis}

Null hypothesis: There is no significant relationship between knowledge management process and effectiveness of classroom delivery

Alternate hypothesis: There is a significant relationship between knowledge management process and effectiveness of classroom delivery

\begin{tabular}{|c|c|c|c|c|c|c|}
\hline \multicolumn{7}{|c|}{ ANOVA $^{\mathrm{a}}$} \\
\hline \multicolumn{2}{|c|}{ Model } & Sum of & df & Mean & $\mathbf{F}$ & Sig. \\
\hline 1 & $\begin{array}{l}\text { Regress } \\
\text { ion }\end{array}$ & 21.454 & 3 & 7.151 & 6.753 & $.000^{\mathrm{b}}$ \\
\hline & $\begin{array}{l}\text { Residu } \\
\text { al }\end{array}$ & 117.538 & 111 & 1.059 & & \\
\hline & Total & 138.991 & 114 & & & \\
\hline
\end{tabular}

a. Dependent Variable: Effectiveness

b. Predictors: (Constant), Knowledgeapplication, Knowledgegeneration, Knowledgestorage

From the above table it is noted that independent variables: Knowledge application, Knowledge generation, Knowledge storage possess a significant relationship on the effectiveness in the classroom delivery. The significance value is 0.000 which is less than $5 \%$ level of significance, hence the null hypothesis is rejected and alternate hypothesis is accepted.

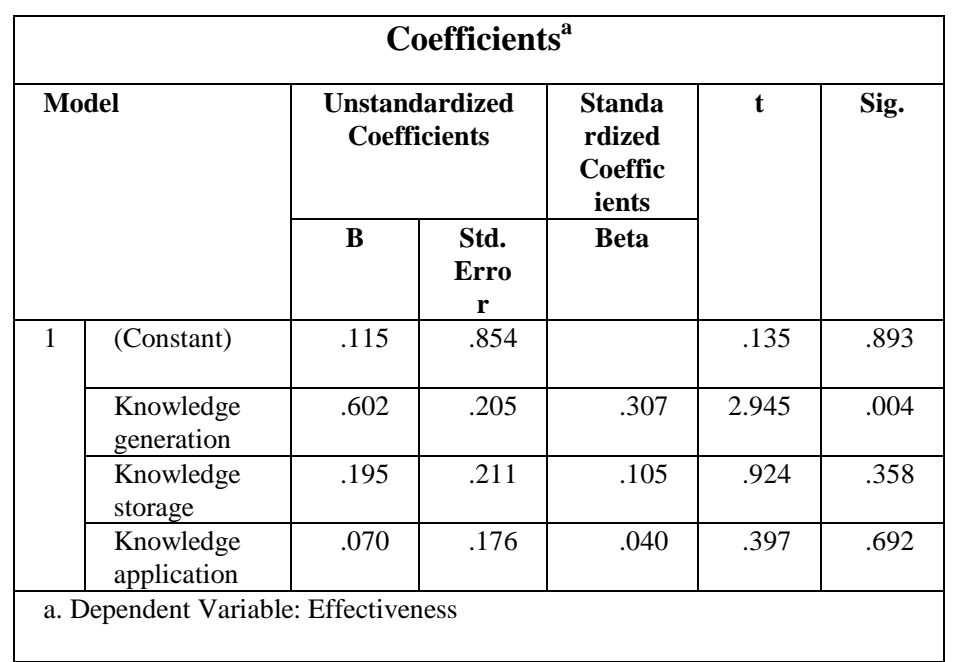

From the above coefficients table, the regression equation can be stated as follows:

$\mathrm{Y}$ (Dependent variable) $=$ Constant $+\mathrm{a}$ X1 (Independent variable 1) + b X2 (Independent variable 2) + c X3 (Independent variable 3 )

Based on the analysis the regression equation is stated as $\mathrm{Y}$ (Effectiveness of classroom delivery) $=0.115+$ 0.602 Knowledge generation +0.195 Knowledge storage + 0.070 Knowledge application

Therefore based on the above, knowledge generation is considered as the critical factor in the knowledge management process in effectiveness of classroom delivery

\section{CONCLUSION}

Thus from the above it can be stated that knowledge management possess greater impact on the effectiveness in the classroom delivery, the knowledge generation is considered as the critical factor in the KM model which was stated earlier. Hence, educational institutions tend to focus on the three specified critical areas: Knowledge generation; Knowledge storage and Knowledge application. These aspects will enable the trainers to enhance the effectiveness of classroom delivery in educational institutions.

\section{REFERENCES}

[1] Bhatt, Ganesh D., (2000) "Organizing knowledge in the knowledge development cycle", Journal of Knowledge Management, Vol. 4 Issue: 1 , pp. $15-26$

[2] Davis, K. (2009), Human Behavior at Work, New York: McGrawHill.

[3] Dessler, Gary. (2010), "Human Resource Management", New Jersey, Prentice-Hall,

[4] Friesl, Martin., Sonja A. Sackmann, Sebastian Kremser, (2011) "Knowledge sharing in new organizational entities: The impact of hierarchy, organizational context, micro-politics and suspicion", Cross Cultural Management: An International Journal, Vol. 18 Iss: 1, pp.71 86

[5] Kubaisi, Salah al-Din. (2005), knowledge management, Cairo: Arab Organization for Administrative Development.

[6] March ,James G \& Sutton ,Robert I.(1997),Organizational performance as A dependent Variable, Organization Science, Vol.(8), No .(6), November-December

[7] Nemati, H. (2002) "Global Knowledge Management: Exploring a Framework for Research.” Journal of GlobalInformation Technology Management, Vol. 5, Issue 3, pp. 1-11. 
[8] Neumann, G and Tomé, E. (2011). “The Changing Role of Knowledge in Companies: How to Improve BusinessPerformance through Knowledge" The Electronic Journal of Knowledge Management Volume 9 Issue 1 (pp57-72),

[9] Seleim,A and Khalil, O.(2007), Knowledge Management and Organizational Performance in the EgyptianSoftware Industry, International Journal of Knowledge Management, Vol.3,No.4.

[10] Tan, C, L and Nasurdin, A, M. (2011), Human Resource Management Practices and Organizational Innovation:

[11] Assessing the Mediating Role of Knowledge Management Effectiveness The Electronic Journal of Knowledge Management Volume 9 Issue 2 (pp155-167) 